\title{
THE ROLE OF THE FEDERAL GOVERNMENT IN THE CON- SERVATION AND UTILIZATION OF WATER RESOURCES
}

\section{James Lawrence Fly $\dagger$}

It is a truism of history that rivers have been the arteries, while their valleys have served as the cradles, of civilization. James Henry Breasted and other great historians have written the stories of nations in terms of their rivers. In America, as elsewhere, expansion has occurred along the lines of the waterways, and the development of those waterways has been a response to the pressure for expansion. River estuaries have afforded many of the best harbors. ${ }^{1}$ Cities built at such locations or near the head of river navigation for ocean-going vessels have served as natural transshipment points for export, import, and coastwise trade. ${ }^{2}$ Our rivers were the highways over which many of the pioneers surged westward. ${ }^{3}$ And the locations of many inland centers of manufacture and commerce were fixed by the geography of the rivers. ${ }^{4}$

From earliest times the use and control of our rivers has been a major concern of government. That concern is evidenced in any account of our national problems, and nowhere better than in the reports of the Supreme Court which have written and reflect so much of our history. Volumes picked almost at random from among the early or recent reports reveal the active interest of government in the waters of the nation.

The Federal Government's responsibility for conservation and utilization of those resources is broadly and deeply rooted in over a century of our history. It covers navigation, flood control, reclamation, irrigation, soil conservation and reforestation, and other beneficial uses of water. But it must be remembered that basically our water resources are unitary. They consist of the waters themselves, the channels in which they flow, and the reservoirs in which they may be stored. Each phase of the problem has its own peculiar history, but all deal with the same basic elements. This article cannot attempt more than to sketch the development of the Government's responsibilities for the principal uses of our water resources. However,

† Graduate, United States Naval Academy, I920; LL. B., I926, Harvard University; member of the New York and Tennessee Bars; General Counsel, Tennessee Valley Authority; author of articles in legal periodicals.

I. National Resources Board Report (I934) 26.

2. Smith, Industrial and Commerctal Geography (new ed. i925) 867-87x.

3. $A$ History of Navigation on the Tennessee River System, H. R. Doc. No. 254, 75th Cong., Ist Sess. (I937) I4-16, 20, 36-37; AMbler, A History OF Transportation IN tere Ohio Valley (i932) 59-80; MacGill, History of Transportation in the United States BEFORE I860 (I9I7) 94 .

4. I Jones \& Whittlesey, An Introduction to Economic Geography (I925) 3i6-3I7; Transportation IN THE Mississippi and Ohio Valleys (Corps of Engineers, U. S. Army, and Bureau of Operations, U. S. Shipping Board, 1929) I82-184. 
it is believed that even this summary will make it clear that, although these responsibilities originated in response to apparently unrelated needs and demands, actually they are all part of a single comprehensive pattern.

\section{Navigation}

The importance of our inland waterways for navigation was recognized long before the founding of the Republic. Washington related that, after one of his early western trips, he "could not help taking a more . . . extensive view of the vast inland navigation of these United States, and could not but be struck with the immense diffusion and importance of it, and with the goodness of that Providence which has dealt his favors to us with so profuse a hand." He concluded, "Would to God we may have wisdom enough to improve them." 5

Responsibility of the Federal Government for the development of the interstate waterways was inevitable. The commercial chaos which had existed under the Articles of Confederation threatened ruin to the colonies. ${ }^{6}$ The need for national control of commerce, in that day largely water-borne, was one of the principal reasons for calling the Constitutional Convention. ${ }^{7}$ The Constitution removed the oppressive tariffs and embargoes. ${ }^{8}$ Acting under its treaty power, the Government secured the right of freedom of navigation of the lower Mississippi and later gained sovereignty over the entire river system. ${ }^{9}$ But this did not end the demand for federal protection and promotion of commerce. The westward expansion of the American people was early accompanied by demands for extensive internal improvements, including the improvement of the waterways. ${ }^{10}$ Strange as it may

5. 5 Marshali, Life of Washington (I807) II.

6. For descriptions of the economic conditions of the period preceding the adoption of the Constitution, see 3 Channing, History of tHe United States (IgI2) c. I5; Fiske, THE Critical Period of Amerrcan History (r888) c. 4; Nevins, The Amierican States During and After the Revolution (1924) 555-568; Warren, The Making of the ConstiTUTION (r928) 85-88.

7. I Elliot, Debates on the Federal Constitution ( 1836 ) IO6-iIg.

8. U. S. Const. Art. I, § Io (2).

9. In the negotiations which led to the formulation of the Treaty of Independence, one of the points which was contended for on the American side was the free navigation of the Mississippi River. The resulting treaty assured this right to the citizens of the United States and Great Britain. But Spain held territory on both sides of the Mississippi at its mouth, and therefore, under a fairly well-recognized principle of international law of that day, had effective control of the navigation of the river. Not until I790 did Jefferson, then Secretary of State under Washington, think the time opportune to push the question, and negotiations were opened which led to the signing, in I795, of the first treaty between the United States and Spain, under which the navigation of the Mississippi was made free to subjects and citizens of the United States. The final and most important step in securing control of the great Mississippi River system was completed in 1803 with the negotiation of the Louisiana Purchase. See $A$ History of Navigation on the Tennessee River System, supra note 3, at 2I-29; Hill, Leading American Treaties (I922) 34, 37, 76-io2; i Malioy, Treaties, ConvenTIONS, Erc. (I9Io) 580-583, 2 id. at I640-1642; N'EviNs, op. cit. supra note 6 , at 345-348; OGG, THE OPENING OF THE MISSISSIPPI (Ig04).

io. Bogart, Economic History of the American People (I935) 3II-3I5; MacGili, op. cit. supra note 3 , at I3I-I36;3 McMASTER, HISTORY OF THE PEOPLE OF THE UNITED States (1892) $465-478$. 
seem from our present perspective, the commerce clause was almost forgotten in the great debates that ensued, and navigation improvement became involved in the controversy over the scope of the federal authority to make internal improvements under the spending power. Beside this great political conflict, the current controversy over the Government in the power business pales into polite dialectics.

Jefferson, Madison, and Monroe, although favorably disposed toward the assumption of responsibility by the Federal Government for navigation and other improvements to facilitate interstate commerce, thought that the Constitution contained no grant of authority for such undertakings. Accordingly, Jefferson and Madison and, at first, Monroe suggested that navigation improvements and other limited works be authorized by specific constitutional amendment. ${ }^{11}$

But the battle as to constitutional authority was soon to be fought on another front, shifting, as have many of our great controversies, from the political to the judicial arena. At the beginning of the nineteenth century, just after the invention of the steamboat, a series of acts of the New York legislature had secured to Fulton and Livingston the exclusive navigation by steamboat upon all navigable waters of the state. Livingston, who, as Ambassador to France, had negotiated the Louisiana Purchase, later successfully negotiated with the territorial legislature for a similar monopoly of Louisiana waterways. Having thus monopolized two of the most important rivers, Livingston and Fulton held the keys to the two chief American ports. A half dozen of the more important coastal states having already conferred upon private interests exclusive rights to the use of their navigable waters, the nation was thus on its way to a monopoly of steamboat transportation in the hands of these gentlemen and a few kindred spirits. ${ }^{12}$

Here again were bitter conflicts, this time between the commercial interests of the various states. This commercial rivalry led to recriminatory statutes by the different legislatures. Litigation thrived. With commerce throttled, civil war threatened. ${ }^{13}$

Fulton and Livingston nevertheless proceeded to parcel out the navigation rights on certain stretches of the waters controlled by them. They assigned the exclusive navigation franchise between Elizabethport and New York City to former Governor Aaron Ogden of New Jersey, who had threatened to compete. Thomas Gibbons, once a partner of Ogden and a citizen of Georgia, who had only a federal license to engage in the coastal trade, traversed that stretch of water. When the New York Court of Errors affirmed Chancellor Kent in sustaining the monopolistic grants and

II. I Richardson, Messages and Papers of the Presidents (I898) 409, 456, 497, 567, $584 ; 2$ id. at $8, \mathrm{I7}, \mathrm{I42}, \mathrm{I44}, \mathrm{I90}, 2 \mathrm{I} 6$.

I2. 4 Beveridge, LIFE OF JoH N Marshall (1919) $4 \mathrm{I} 4$.

13. 2 WarRen, The Supreme Court IN UnIted States History (1923) 58. 
enjoined Gibbons from sailing on New York waters, ${ }^{14}$ Gibbons appealed to the United States Supreme Court.

The case was heard in the heated atmosphere of the states' rights controversy, inflamed by the current congressional debate over a bill to authorize internal improvements. ${ }^{15}$ The brunt of the battle against the steamboat monopoly fell on Webster, then fresh from the arguments in the Dartmouth College case ${ }^{16}$ and $M^{\prime} C$ ulloch $v$. Maryland. ${ }^{17}$ Marshall, with quill in hand, was more favorably poised for Webster's argument than counsel knew. Four years earlier, on circuit, he had already asserted the broad power of Congress over commerce in an opinion of which the great advocates in Gibbons $v$. Ogden were quite unaware. ${ }^{18}$

Marshall's epochal opinion ${ }^{10}$ established for all time the exclusive control of the National Government over interstate navigation. Warren has termed it the "most potent factor in the building up of New York as a commercial center" and "the emancipation proclamation of American commerce." 20 The back of the first great monopoly of the nation's water resources was broken.

The decision did not open a novel field, for the Federal Government had undertaken surveys of the Mississippi and Ohio Rivers prior to that time, ${ }^{21}$ but it was followed by a noteworthy spurt of activity. Another and more comprehensive survey was authorized, ${ }^{22}$ and money was appropriated to remove obstructions from those rivers. ${ }^{23}$ Before the end of the year President Monroe forwarded to Congress the report of Secretary of War Calhoun, which recommended an ambitious plan of integrated roads, canals, and improved rivers interconnecting various parts of the United States, including the improvement of the Tennessee River at Muscle Shoals. ${ }^{24}$

The states' rights theory, however, exerted some influence on the angle of approach. Thus, in 1828 , Congress made the first of a series of futile

14. Gibbons v. Ogden, I7 Johns. 488 (N. Y. I820).

I5. 4 BEVERIDGE, op. cit. supra note I2, at $4 \mathrm{I} 8$.

16. Dartmouth College v. Woodward, 4 Wheat. 5 I8 (U. S. I8Ig).

17. 4 Wheat. 3 I6 (U. S. I8I9).

18. The Wilson v. United States, 30 Fed. Cas. No. r7,846 (C. C. D. Va. I820).

19. 9 Wheat. I (U. S. 1824 ).

20. 2 WARREN, op. cit. supra note 13 , at 76 .

21. By the terms of 3 STAT. 562,563 (I820), $\$ 4,500$ was appropriated "for making a survey of the water-courses tributary to, and west of, the Mississippi, also those tributary to the same river and north-west of the Ohio", and another sum of $\$ 5,000$ "for making a survey, maps, and charts, of the Ohio and Mississippi rivers, from the rapids of the Ohio at Louisville, to the Balize, for the purpose of facilitating and ascertaining the most practicable mode of improving the navigation of those rivers". The report of the survey made by the Board of Engineers was communicated to Congress by President Monroe on Jan. 22, I823, 2 RrCEARDSON, op. cit. sipra note II, at I99, and was later published in 2 AMrERICAN State Papers: COMMERCE \& Navigation (I834) 740-746.

22. 4 Stat. 22 (I824) (of such roads and canals as the President might deem to be of national importance).

23. Id. at 32.

24. 2 American State Papers: Military Affairs (1834) 698-701; 2 Richardson, op. cit. supra note II, at 255,257 . 
land grants to the states, giving to Alabama four hundred thousand acres to induce the improvement of navigation at Muscle Shoals. ${ }^{25}$ As the National Government moved gingerly in the assumption of direct responsibility, ${ }^{26}$ popular sentiment increasingly favored the Government's development of the inland waterways. ${ }^{2 \pi}$

By the middle of the century when the states' rights controversy had become focused on other issues, President Fillmore, in his first annual message, recommended that the Federal Government undertake direct works for waterway improvements, for the reason, as he said, "that if these works, of such evident importance and utility, are not to be accomplished by Congress they can not be accomplished at all." 28 On the constitutional question under the commerce power, he entertained no doubts. "The magnificent Mississippi and its tributaries," he said, "appear to me to fall within the exercise of the power as justly and as clearly as the ocean and the Gulf of Mexico. It is a mistake to regard expenditures judiciously made for these objects as expenditures for local purposes." 29

With the feverish expansion of the railroads, water transportation was relatively neglected. ${ }^{30}$ Nevertheless, by $\mathrm{I} 882$ the Government had spent over a hundred million dollars on its rivers and harbors. ${ }^{31}$ And, as the country became more permanently settled, a clearer picture of our transportation needs gave new emphasis to such improvement. ${ }^{32}$

Meanwhile, the courts were laying the legal foundation for broad national development of water resources. An early attempt of private interests, acting under state authority, to encroach upon the paramount rights over navigation met with failure in the Supreme Court. ${ }^{33}$ Later efforts of the Federal Government in clearing the rivers of obstructions to navigation were consistently upheld. ${ }^{34}$ When an attempt was made to limit the Govern-

25. 4 Stat. 290 (I828), amended by 4 Stat. 397 (I830), 4 STat. 44 I (I83I), 4 Stat. 604 (1832), 5 STAT. 57 (1836); see $A$ History of Navigation on the Tennessee River System, sitpra note 3, at I25-I28; HibBaRd, A HistoRy OF THE PUBLIC LAND Polictes (I924) 240-24I.

26. Appropriations and Expenditures for Rivers and Harbors, H. R. Exec. Doc. No. 64, 48 th Cong., Ist Sess. (I884) ; SEN. Doc. No. 72, 21st Cong., 2d Sess. (I83I) (message from the President in answer to a resolution of the Senate relative to the application of the appropriations for the improvement of the Ohio and Mississippi Rivers); 2 RICHARDSON, op. cit. supra note II, at $483,508-517$.

27. See SEN. Doc. No. I37, 27th Cong., 3d Sess. (I843) (report of the Committee on Commerce, to which were referred sundry memorials asking Congress to make an appropriation to improve the navigation of the Mississippi River and its principal tributaries).

28. 5 RiCHARDSON, op. cit. supra note Ir, at 90 .

29. Id. at $9 \mathrm{I}$.

30. Ambler, op. cit. supra note 3, at I85-209; Clowes, Shipways to the Sea (I929)

$3 \mathrm{x}$; Transportation IN THE Mississippi and OHIo Valleys, supra note 4 , at I70-172.

3I. Appropriations and Expenditures for Rizers and Harbors, supra note 26 , at 285 .

32. See 8 Richardson, op. cit. supra note II, at 6I9; TRANSPORTATION BY WATER (Bureau of the Census, Ig06) Ig0-r93.

33. Pennsylvania v. Wheeling \& Belmont Bridge Co., I3 How. 5 I8 (U. S. I85I).

34. United States v. Rio Grande Irrigation Co., I74 U. S. 690 (1899); United States r. Bellingham Bay Boom Co., I76 U. S. 21T (I900); Union Bridge Co. v. Únited States, 204 U. S. 364 (I907) ; Monongahela Bridge Co. v. United States, 216 U. S. I77 (I910) ; Hanni- 
ment to regulatory activities, the Supreme Court merely referred to Marshall's decision, saying that the Government's right "rests upon principles of constitutional law now established beyond dispute." 35 Similar protests against the construction of navigable channels and the Panama Canal were disposed of in turn. ${ }^{36}$ And suits by riparian owners seeking to recover consequential damages for impairment of property values resulting from navigation improvements were generally unsuccessful..$^{37}$

Water power, a valuable by-product of navigation structures, suggested a means of reimbursement to the Government. And the Court at once recognized the relation of the water power to the physical structure which had concentrated the fall at a single point. Efforts of states and private interests to secure to themselves a portion of the resources captured by such structures were, alike, met by statements such as that classic sentence in the Green Bay case, "In such matters there can be no divided empire." 38

The development of our rivers by no means kept pace with the scope of congressional power as defined by the Supreme Court decisions. At the turn of the century the conservation movement, then taking stock of our natural resources, found that the water resources had been far from adequately developed or exploited. ${ }^{39}$ In I908, Theodore Roosevelt complained of the neglected condition of our waterways and of the small part they played in the industrial life of the nation, despite the fact that, as he said, "in extent, distribution, navigability and ease of use [our rivers] stand first." 40

The World War dramatized this inadequacy. Existing transportation was unable to carry the burdens of wartime traffic. ${ }^{41}$ As a demonstration of what could be done to round out the national system, the Inland Waterways Corporation was created in $1924 .{ }^{42}$ The renewed interest in waterways

bal Bridge Co. v. United States, 22r U. S. I94 (xorI) ; Philadelphia Co. v. Stimson, 223 U. S. 605 (I9I2); Louisville Bridge Co. v. United States, 242 U. S. 409 (I9I7); Economy Light \& Power Co. v. United States, 221 U. S. II3 (I92I). See Blair, Federal Bridge Legislation and the Constitution (I927) 36 Y ALE L. J. So8.

35. Luxton v. North River Bridge Co., I 53 U. S. 525, 529 (I894).

36. Wisconsin v. Duluth, 96 U. S. 379 (I877); Wilson v. Shaw, 204 U. S. 24 (I907).

37. Gibson v. United States, I66 U. S. 269 (I897); Scranton v. Wheeler, x79 U. S. I4I (I900) ; Bedford v. United States, 192 U. S. 217 (1904); United States v. Chandler-Dunbar Co., 229 U. S. 53 (I9r3); Jackson v. United States, 230 U. S. I (I913); Hughes v. United States, 230 U. S. 24 (19I3) ; Cubbins v. Mississippi River Comm., 24 I U. S. 35 I (I9I6); cf. United States v. Lynah, I88 U. S. 445 (Ig03).

38. Green Bay \& Miss. Canal Co. v. Patten Paper Co., I72 U. S. 58, 80 (I898). Other cases in this field are Kaukauna Water Power Co. v. Green Bay \& Miss. Canal Co., I42 U. S. 254 (189I) ; United States v. Chandler-Dunbar Co., 229 U. S. 53 (I913); Waters v. Phillips, 284 Fed. 237 (C. C. A. 7 th, r922).

39. Preliminary Report of Inland Waterways Commission, SEN. Doc. No. 325, 6oth Cong., Ist Sess. (Ig08) I7-32; I Report of National Conservation Commission, SEN. DoC. No. 676, 6oth Cong., 2d Sess. (Ig09) $21-24$.

40. Preliminary Report of Inland Waterways Commission, supra note 39, letter of transmittal, at 15 -I6.

4I. Dimock, Developing America's Waterways (1935) I; Transportation in the Mississippi AND OHio Valieys, supra note 4, at I80; Ashburn, Inland Waterway Transportation-A National Problem (I934) I7I ANNALS I98.

42. 43 Stat. $360^{\prime \prime}$ (Ig24), 49 U. S. C. A. \& I5I et seq. (Supp. I936). 
beginning with the conservation movement was, meanwhile, evidenced by expenditures of nearly a billion dollars on river and harbor improvements from Igo6 to I925. ${ }^{43}$

Conditions of economic and social unbalance looked to water transportation as a possible remedy. Herbert Hoover, then Secretary of Commerce, stated the case in an address to the Mississippi Valley Association in 1927. He urged that:

“. . . in our necessity to remake and energetically construct... flood control works . . . we must not be diverted from our march to the improvement of our inland waterways. . . . The urgency of the situation to be remedied, to a large degree, grows from the economic shifts due to the war which have brought a new setting to all our midContinent. . . . Mid-West agriculture and Mid-West industry have been placed in a new relationship to different parts of our country and to the world markets as a whole. If we would restore these former relationships, we must find fundamentally cheaper transportation for our grain and bulk commodities which we export and the raw materials which we import into the Mid-West." 44

Mr. Hoover's emphasis on the war as the cause of these unbalances may seem exaggerated, but with the fundamental soundness of his analysis there can be no quarrel. Some of the conditions which he described predated the war and were aggravated by the completion of the Panama Canal. For example, the canal enabled Atlantic seaboard industries to take west coast business from inland industries actually located much nearer the market. And the converse process was also true. ${ }^{45}$ Indeed, the inland producers were in the middle of a cross ruff. The rates of intercoastal rail lines have tended to be fixed at levels competitive with the parallel water routes. ${ }^{46}$ The advantages of communities accessible to waterway transportation thus became further entrenched. And as the situation has become more and more acute, plans for the comprehensive development of inland navigation have evolved. ${ }^{47}$

Technological advances have played a large part in making these plans feasible. Improved water transport facilities have paralleled improvements in methods of channel development. There are today almost thirty thousand

43. Report of the Mississippi Valiex Committee of the Public Works AdminisTRATION (Fed. Emerg. Adm'n of Pub. Works, 1934) 37. I6-I7.

44. Hoover, The Improvement of Our Mid-West Waterways (1928) I35 ANNaLs I5,

45. Interstate Commerce Commission Hearings on Rail and Barge Joint Rates, Docket No. 26,712; Joint Hearings before Commission of Interstate Commerce and Merchant Marine Sub-Committee of Committee on Commerce on $S$. 1632 , 74th Cong., Ist Sess. (1935) pt. 2; Mears, Maritime Trade of Western United States (I935) c. 6; I Recent Economic Changes (I929) 3I5-3I7.

46. FAgG AND WHLLER, FReight TRaffic REDbook (I937) IOI-II7.

47. See Preliminary Report of President's Commission on Development of the Rivers of the United States, H. R. Doc. No. 395, 73d Cong., 2d Sess. (I934); National Resources BOARD REPORT (I934) 26-30; REPORT OF THE MISSISSIPPI VALLEY CoMMITTEE, supra note 43; RePORT OF THE TENNESSEe Valley Authority (I936) c. I. 
miles of navigable waterways already improved or under improvement, including about six thousand miles of standard nine-foot depth. ${ }^{48}$ Today river transportation of commodities compares favorably with any other transportation as to speed, dependability, ease of handling, and operating costs. ${ }^{49}$ Traffic is increasing annually. ${ }^{50}$ There may still be some who, as Mr. Hoover humorously remarked, conceive the development of the waterways as a visionary effort which is designed to do no more than "restore the romantic steamboatin' days with gay river steamers whistling down the reaches, with possible Mark Twains aboard." 51 To any such it may be observed that they are unaware of some of the most important economic developments of the last generation. ${ }^{52}$

\section{Flood Control}

The I927 flood on the lower Mississippi destroyed whatever remained of insular thinking on the flood problem. With dramatic suddenness it brought home to the nation its second major responsibility in the control of inland waters. The pioneers who settled along the paths of the river highways settled also in the paths of the great floods.

In the early days, flood control was regarded largely, but by no means exclusively, as a local responsibility. While political considerations may have had some influence in this attitude, the problem actually appeared to be local. The country was relatively undeveloped; population and industry were scattered; sections were comparatively self-contained. The first federal aid was accordingly confined to limited land grants to the affected states. ${ }^{53}$ But federal surveys and studies were subsequently authorized and completed, ${ }^{54}$ and these culminated in the establishment of the Mississippi River

48. Report of the Mississippi VAlLey Committee, supra note 43 , at $38,39$.

49. I FREIGET TRAFFic REPoRT (Fed. Coordinator of Trans. I935).

50. See Annuad Reports of the Chibf of Engineers, U. S. Army.

5I. Hoover, supra note 44 , at 19.

52. See Sumner, An Analysis of Mississippi River Traffic (I93I) 7 J. of LaNd \& Pub. UTIL. ECON. 355, (1932) 8 id. II.

53. 9 Stat. 352 (1849); 9 Stat. 519 (I850). According to Flood Control in the Mississippi Valley, H. R. REP. No. I072, 70th Cong., Ist Sess. (I928) Ir4-II5, the patented areas, by States, were as follows: Arkansas, 7,686,455.37 acres; Louisiana, 9,405,929.24 acres; Mississippi, 3,288,418.50 acres; and Missouri, 3,346,936.01 acres.

54 Congressional authorizations were as follows : 9 STAT. 523, 539 (1850) ; Io Stat. I05, IO7 (I852); I8 STAT. I99 (I874). See also Sen. Res. of June Ir, I866, published in CoNG. GroBE, 39th Cong., Ist Sess. (I866) 3075. The official reports are: SEN. ExEc. Doc. No. 20,

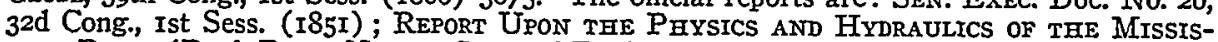
SIPPI RIVER (Prof. Paper No. 13, Corps of Engineers, U. S. Army, I86I) ; SEN. Exec. Doc. No. 8, 40th Cong., Ist Sess. (1866); H. R. ExEc. Doc. No. I27, 43 d Cong., 2d Sess. (1875). The last report contains the following significant remarks concerning the ineffectiveness of local organization:

"In fine, then, the experience of over one hundred and fifty years has utterly failed to create judicious laws or effective organization in the several States themselves, and no systematic co-operation has ever been attempted between them. The latter is no less important than the former, for the river has no respect for State boundaries, and deluges Arkansas through breaks in the levees of Missouri, and overflows Louisiana by floods passing across the Arkansas line. 
Commission in 1879.55

In making the first appropriation for the work of the Commission, Congress, apparently of the opinion that the federal interest should be limited to navigation improvement, prohibited the use of federal funds for the construction and repair of levees for flood control "or for any other purpose . . . except as a means of deepening . . . the channel of said river." 56 President Arthur, however, seems to have had a broader view of the problem. Thus, in his special message to Congress recommending favorable consideration of a report on flood control submitted by the Commission in I882, he said:

"The constitutionality of a law making appropriations in aid of these objects cannot be questioned. While the report of the Commission submitted and the plans proposed for the river's improvement seem justified as well on scientific principles as by experience and the approval of the people most interested, I desire to leave it to the judgment of Congress to decide upon the best plan for the permanent and complete improvement of the navigation of the river and for the protection of the valley." 57

Until I89o, however, the appropriations for the Commission contained the proviso that all funds had to be spent for the improvement of navigation. ${ }^{58}$ But beginning with that year and until I9I7, the appropriation measures contained provisions permitting expenditures of funds not only to improve navigation but also to promote the broader interests of commerce. ${ }^{59}$ During this period levee districts and other local governmental units continued to bear a large part of the financial burden and responsibility for protecting overflow areas against floods. ${ }^{60}$

Following the rgr 6 flood, Congress authorized a substantial appropriation for the flood control of the Mississippi, ${ }^{61}$ and the Flood Control Act of $1923^{62}$ provided still more liberal amounts. These were the first real floodcontrol acts. Though they embodied the principle of local contribution, the

"It is a common and apt figure of speech to personify the Mississippi, and to speak of the conflict waged to protect the country against the inroads of a terrible enemy, and yet the army of defense has always been content to remain a simple aggregation of independent companies, with here and there a battalion under the command of a board of officers. That victory has not more frequently perched upon their banners is surely not surprising." Id. at I9.

55. 2 I Stat. 37 (I879).

56. 2I Stat. 468,474 (I88I).

57. 8 RICHARDSON, op. cit. silpra note II, at 95 .

58. 22 Stat. Igt, 208 (I882) ; 23 Stat. I, I33, I46 (I884); 24 Stat. 310, 329 (I886) ; 25 Stat. $400,42 \mathrm{~T}$ (I888).

59. 26 Stat. 426, 450 (i890). See Annual Report of the Chief of Engineers, U. S. ARMY (I9I3) 3352 .

6o. For the history of local efforts to control floods on the Mississippi, see Report on Internal Commerce of the United States, H. R. Exec. Doc. No. 6, 50th Cong., Ist Sess. (I888) pt. 2, 234-263; Flood Control in the Mississippi Valley, supra note 53; Frank, DEvelopment of the Federal Program of Flood Control on the Mississippi River (I930)

c. 7. See also Jackson v. United States, 230 U. S. I, I9 (I9I3).

6I. 39 STAT. 948 (IgI7).

62. 42 Stat. I505 (1923), 33 U. S. C. A. \$702 et seq. (1928). 
national character of the flood-control problem was coming to be more fully understood. Finally, with the occurrence of the 1927 flood disaster, there developed a general recognition that the control of a great flood is a national problem which can only be solved by the most comprehensive national measures. ${ }^{63}$

The physical problem of controlling the flow of a river involves the entire drainage basin. Our greatest and most unruly river drains thirty-one states and over forty per cent of the country. ${ }^{64}$ We have now come to appreciate the fact that floods are caused by rains hundreds of miles from the flooded zone. The area affected by the flood itself is tremendous in size. Local protection cannot possibly cope with the problem. To take one of countless examples, a local levee has frequently increased the hazard of other affected areas.

In recent years the flood problem itself has intensified. The rate of water run-off from the land has been accelerated by the stripping of forest and plant cover from the soil. ${ }^{65}$ The intensity of floods has naturally increased, and new flood heights continue to be registered. ${ }^{66}$ With the concentration of industries, property, and population in the river valleys, the havoc wrought by floods becomes progressively worse, and correspondingly the national interest becomes greater. While the floods of I9I2 and I927 covered approximately the same land areas, the damage caused by the latter flood was

63. As a result of the study of the flood-control problem of the Mississippi River, the Flood Control Committee of the Chamber of Commerce of the United States recommended that the Federal Government should assume the sole responsibility for locating, constructing, and maintaining works necessary to control the floods of the lower Mississippi River. Delano, The Report of the Committee on Mississippi Flood Control Appointed by the United States Chanber of Commerce (I928) I35 ANNALS 25.

The Executive Council of the American Bankers' Association, meeting at Hot Springs, Arkansas, adopted a resolution demanding federal action to prevent floods such as the I927 flood on the lower Mississippi. N. Y. Times, May 5, I927, p. 2, col. 4.

The Investment Bankers Association, at its convention in Seattle in 1927, declared by resolution that floods on the Mississippi "affect and impair the economic welfare of this entire nation." Comm. \& Fin. Chron., Oct. I5, I927, p. 2074, col. 2.

Herbert Hoover, then Secretary of Commerce, made this statement during his inspection tour of the flooded area: "Thirty States have contributed water to this flood, but of more positive interest is the fact that no part of the nation can suffer a loss without that loss reflecting on every other part. The people in this vast region who contribute so much to national wealth and prosperity should be relieved of this anxiety and terror. It is a national problem and must be solved nationally and vigorously." $N$. Y. Times, April 2S, 1927, p. 2, col. 2.

64. Paul, Inventory of the Water Resources of the Mississippi River Drainage AREA (Nat. Resources Bd. I935) I-3.

65. See A National Plan for American Forestry, SEN. Doc. No. I2, 73d Cong., Ist Sess. (1933) 25-29, 298-46I; Relation of Forestry to the Control of Floods in the Mississippi Valley, H. R. Doc. No. 573, 70th Cong., 2d Sess. (I929) I-5I ; Zon, Forests and Water in Light of Scientific Investigation in Final Report of National Waterways Commission, SeN. Doc. No. 469, 62d Cong., 2d Sess. (I9I2) 205; GLENN, Denudation and Erosion IN THE SoutheRN A ppalachian Regron (Prof. Paper 72, U. S. Dep't Int. rgxx) 25-30; Swain, Conservatron of Water by Storage (I915) c. 7; Sherman, What Forests Can Do for the Mississippi River (1928) I35 ANNALS 45.

66. Thomas, Basic Factors in Flood Frequency in the Lower Mississippi River (1928) I35 ANNALS I. 
four times that of the earlier one. ${ }^{67}$ Today everyone in the country suffers from a major flood catastrophe.

The Flood Control Act of $1928^{88}$ was drafted to meet a critical emergency created by the flood of the year before. There was not time to make the comprehensive engineering studies which Congress recognized were needed. The Act provided immediately only for a continuation of flood control by extension of the levee system and diversion floodways. ${ }^{69}$ But at the same time it directed the early completion of studies which were then under way looking toward supplementing the levees by a system of tributary reservoirs. ${ }^{70}$

The system of flood protection relied on in the past has consisted mostly of levees designed to confine the water to the rivers. The natural result has been an increase in flood heights with resulting difficulties. ${ }^{71}$ The residents of the Mississippi alluvial valley are demanding that floods be controlled by reducing their height rather than by confinement. In a recent public meeting, the speaker for a Mississippi Valley city said, "We want the Mississippi River floods controlled, but we want them controlled down, not up." Of course, the present comprehensive system of levees is of great importance in controlling destructive flood waters in the lower Mississippi. Indeed, these levees are necessary. But it is clear, and now generally recognized that levees must not be depended upon as the sole means of protection; they must be supplemented. Recent studies indicate that reservoirs are indispensable for effective reduction of flood heights, ${ }^{72}$ and the legislation subsequent to the 1928 Act has made provision for reservoir control. ${ }^{73}$ Such a system emphasizes more than ever before the interrelationship and interdependence of navigation and flood control recognized by the Supreme Court in Jackson v. United States. ${ }^{74}$ The same structure which holds back the waters in times of flood provides the flow for maintaining a navigable channel in dry seasons. As elsewhere, engineering conclusions were translated into legal principle as the Court enunciated the legal relation of the flood problem to "the plenary power of the United States to legislate for the benefit of navigation. . . ."75

67. Id. at 3-4.

68. 45 Stat. 534 (1928), 33 U. S. C. A. \$ 702a et seq. (Supp. 1936).

69. Id. at 535,33 U. S. C. A. § 702a.

70. Id. at 538, 33 U. S. C. A. $\$ 702$ j.

71. Hazen, Flood Flows: A Study of Frequencies and Magnitudes (i930) i72.

72. See Comprehensive Report on Reservoirs in Mississippi River Basin, H. R. Doc. No. 259, 74th Cong., Ist Sess. (1936); The Ohio River, H. R. Doc. No. 306, 74th Cong., Ist Sess. (I936); Report of the Chief of Engineers, Coma. Doc. No. I, 75th Cong., Ist Sess. (I937).

73. 49 STAT. I570, 33 U. S. C. A. § 7ora (Supp. 1936). See also the Tennessee Valley Authority Act, 48 STAT. 58 (I933), as amended by 49 StAT. 1075 (I935), I6 U. S. C. A. § 831 et seq. (Supp. 1936).

74. 230 U. S. I (I9ז3). See Bedford v. United States, I92 U. S. 217, 223 (I904) ; Cubbins v. Mississippi River Comm., 24I U. S. 35I, 369 (I9I6).

75. 230 U. S. I, 23 (rgI3). 


\section{Irrigation}

Our last important pioneering movement, the settlement of the arid regions of the West, was responsible for the third major phase of the Government's interest in water control. In aid of this movement, provision was made for sales of public lands at nominal prices to settlers who would take the steps necessary to reclaim them. ${ }^{76}$ In the Carey Act, ${ }^{77}$ Congress inaugurated the plan of turning over to the states arid lands for reclamation by any means which they might choose to adopt. And Congress enacted other legislation providing for grants of rights of way over the public domain for canals and ditches used for irrigation purposes. ${ }^{78}$ But all of these measures failed to further in any substantial measure the Government's longestablished policy of encouraging the settlement of the public domain in small individual holdings. ${ }^{79}$ Finally, in I902, Congress enacted the Reclamation Act ${ }^{80}$ and the Department of Interior undertook irrigation and reclamation projects on an extensive scale. ${ }^{81}$ As amended by the Act of April r6, 1906, ${ }^{82}$ which provided for the disposition of the surplus electric power made available at the projects, this law has fixed the general policy of the Federal Government with regard to irrigation and reclamation.

At the outset, the constitutionality of the reclamation measures was confidently attacked. True to the traditional opposition of private interests, it was urged that these laws were designed to put the Government into the real estate business. The minority report on the Reclamation Act of 1902 accused its proponents of turning the Government into a "real estate improvement society." 83 But the courts could not fail to recognize the larger aspects of the problem. ${ }^{84}$ The Act was held valid under the property clause as a means

76. 18 Stat. 497 (1875); 19 Stat. 377 (I877), 43 U. S. C. A. \$§ 32I-323 (I928), as amended by 26 STAT. 1095 (I89T), 43 U. S. C. A. \$ II8I (I928).

77. 28 Stat. 422 (I894), 43 U. S. C. A. \$64I (I928). 'See VAN Hise \& HaveMreyer, Conservation of Our Natural Resources (I93I) I52.

78. I4 Stat. 253 (I866), 43 U. S. C. A. \$946 (I928); 28 Stat. 635 (1895), as annended by 30 STAT. 404 (I898), 43 U. S. C. A. § 956 (I928); 3I Stat. 790 (Igor), 43 U. S. C. A. $\$ 959$ (1928).

79. See United States v. Hanson, 167 Fed. 881, 883 (C. C. A. 9th, 1909) ; First Amunal Report of the Reclamation Service, H. R. Doc. No. 79, 57th Cong., 2d Sess. (Igor) 3I-60.

80. 32 STAT. 388 (I902), 43 U. S. C. A. \$39I (I928). This legislation had been recommended by President Theodore Roosevelt in his message to Congress of Dec. 3 , rgor. See Richardson, Messages and Papers of the Presidents (Supp. rg03) 33I-332. Precedents for legislation of this character already existed. See Joint Resolution of March 20, 1888, 25 Stat. 6r8; 25 Stat. 505, 526 (I888) ; 25 Stat. 939, 960 (I889).

8r. See VAN HISE \& HAVEMEYER, op. cit. supra note 77, at r54-r64.

82. 34 Stat. II7 (Ig06).

83. H. R. REP. No. 794, 57th Cong., Ist Sess. (Ig02) pt. 2, io.

84. A somewhat similar problem had been considered by the Court in I840. In United States v. Gratiot, I4 Pet. 526 (U. S. I840), the leasing of public mineral lands was challenged on the ground that it would place the Federal Government in a continuing business and create a federal "tenantry" within the states. The Court held that the property might be disposed of in the public interest pursuant to the property clause of the Constitution and that the choice of a method of disposal was a matter for the discretion of Congress. 
of improving the public domain to make it marketable. ${ }^{85}$ It was expressly approved by the Supreme Court in Kansas v. Colorado. ${ }^{\mathbf{s 6}}$

The giant reclamation projects, like Roosevelt, Boulder, and Grand Coulee, are also concerned with other purposes, such as navigation, flood control, and the development of hydroelectric power. ${ }^{87}$ But in so far as irrigation is concerned, they are examples of the present-day execution of the policy determined by the original reclamation acts. Naturally, as the reclamation policy has developed, the Government has been concerned with storing and providing water for private arid lands, as well as the public domain. Whatever doubts there may have been in Kansas v. Colorado concerning such practices, it is clear under Arizona v. California, ${ }^{88}$ the Supreme Court's decision last term in the Boulder Dam litigation, that the Government has come to have a controlling interest in the disposition of the waters impounded by its multiple-purpose projects.

\section{Planning for Multiple Purposes}

Limitations of space have precluded any discussion of a number of incidental water problems, such as those involving pollution ${ }^{89}$ and recreation. ${ }^{90}$ As to the major uses, an effort has been made to state in brief outline the history which has inevitably given the National Government a predominant position in the control and utilization of water resources. The most notable and interesting feature of this deep-rooted history has been the gradual recognition of the inseparability of the various phases of the subject and the necessity for laying plans on a broad base in order to produce multi-purpose projects of maximum usefulness.

In the early years most of the projects, whether public or private, were designed for only one purpose. When there was need for river improvement for transportation and commerce, a navigation dam or lock or a canal was constructed, or dredging was carried on. If water was needed for irrigation, a canal or dam and reservoir was designed solely for irrigation. If a local flood hazard became apparent, a levee or spillway was provided. If an industry, a city, or a utility needed power, a dam was designed for power alone. If a problem of pollution arose, steps were taken to meet it without any consideration of the pattern of water control as a whole. Each need was separately met on its own individual merits. Other uses were overlooked, and the needs of adjoining regions went unattended.

85. United States v. Hanson, I67 Fed. 881 (C. C. A. 9th, I909) ; Burley v. United States, r79 Fed. I (C. C. A. 9th, I9Io).

86. 206 U. S. 46,92 ( 1907$)$.

87. See 42 Stat. 847 (I922), 43 U. S. C. A. $\$ 598$ (I928); 45 Stat. I057 (I928), 43 U.

S. C. A. \& 617 (Supp. 1936); 49 STAT. I028, 1039 (I935).

88. 298 U. S. 558 (1936), rehearing denied, 299 U. S. 618 (I937).

89. See National Resources Board Report (I934) 333-339; Report of MIssissippi VALley CoMmitTeE, supra note 43 , at 5, 55-60.

90. See National Resources Board Report (I934) 345-346; Report of Mrssissippi VALLEY CoMmitteE, supra note 43 , at 9I-95. 
The construction of multiple-purpose projects by the Government was not the result of any a priori theory. The facts determined the policy, and policy developed as existing facts were recognized. A striking example is afforded by the manner in which the Government became concerned with the production of electricity at reclamation projects. When large-scale federal reclamation began thirty-five years ago, the opportunities to generate power as an adjunct to irrigation were so little appreciated that they were ignored in the act of I902.01 But power was there, whether the Government was interested in it or not. Discovering that it was already the owner of valuable water power falling over the dams, Congress thereupon amended the act ${ }^{92}$ to provide for the disposal of the surplus.

Even before this, Congress had seized upon special opportunities for undertakings having more than one purpose. An early act, for example, authorized projects combining irrigation and flood control. ${ }^{93}$ Others provided for the disposition of surplus water power at navigation dams. ${ }^{94}$ And grants of privileges to private interests for the construction of power dams in navigable rivers required the installation of navigation facilities. ${ }^{95}$

But the full significance of projects combining more than one purpose did not appear until the increasing utilization of our water resources, made possible by engineering progress, enhanced the importance of the natural relationships among the various uses of waters. When the development of modern engineering methods had made possible and necessary the construction of huge dams and storage reservoirs, the possibilities both for integration and for conflicts multiplied. ${ }^{96}$ Integration was no longer merely desirable: it had become essential to avoid serious conflict and waste. The nature and causes of these conflicts and interrelations are so important that it is worth while to discuss them for a moment.

Most of the conflicts are obvious. Water diverted from a stream to serve one community or industry depletes the supply available for others. ${ }^{.7}$ A hydroelectric power installation may utilize all of the storage of a reservoir before the season of low-water navigation. ${ }^{98}$ A storage reservoir utilized solely for controlling floods may not serve to best advantage the

9r. 32 STat. 388 (I902), 43 U. S. C. A. §39r (r928).

92. 34 Stat. II7 (I906), 43 U. S. C. A. $\$ 522$ (1928).

93. 25 STAT. 505, 526 (I888).

94. 25 STAT. 400 , 4I7 (I888); 26 STAT. 426, 447 (I890); 32 Stat. 408,409 (rg02). See also 20 STAT. 387 (I879), authorizing the Secretary of War to dispose of certain water power by lease.

95. 33 Stat. 309 (1904) ; 33 Stat. 7I2 (I905).

96. Baker, The Necessity for State or Federal Regulation of Water Power Development (Ig09) 33 Annals 583.

97. See Connecticut v. Massachusetts, 282 U. S. 660 (I93I) ; New Jersey v. New York, 283 U. S. 336 (I93I).

98. See Bixby, The Practicability of Storage Reservoirs to Prevent Floods and to Benefit Navigation of the Ohio and Other Rivers of the United States in Final Report of National Waterways Commission, SEN. Doc. No. 469, 62d Cong., 2d Sess. (I912) 185, 199. 
interests of navigation, irrigation, and power. ${ }^{99}$ If a reservoir is used for the sole purpose of controlling floods on a single tributary of the Mississippi, it may discharge the stored water on the crest of a flood on the lower Mississippi itself. ${ }^{100}$

Planning of integrated multiple-purpose projects not only minimizes these conflicts as far as possible but results in multiple benefits through avoidance of waste. A dam which levels the slope in the river to improve navigation concentrates the water fall and thus creates water power which, with proper facilities, will generate hydroelectric power. The same water which is stored to prevent floods may be released in time of drought to promote navigation, to produce power, and to irrigate arid lands.

Nature has been sparing in the provisions of valuable sites for water storage, long recognized as essential for navigation and irrigation purposes. The recent recognition that storage reservoirs are indispensable to effective flood control in critical areas aggravates the problem of discovering an adequate number of reservoir sites. Many sites which nature has supplied are unavailable, either because of the location of improvements too valuable to permit inundation or because the sites may already be occupied by dams built for limited purposes. It is therefore all the more necessary that such sites as remain available be made to do double or triple duty in the public service.

These double and triple duty projects also make possible the most economical utilization of capital. It is obviously less expensive to provide by a single structure for more than one use of the water than to provide a separate structure for each use. Congress has often felt that the cost of engineering structures for navigation alone or for flood control alone was prohibitive, while a structure serving both navigation and flood-control purposes would be considered amply justified. Some projects which are not economically feasible even for navigation and flood-control purposes combined become feasible by the utilization of the water power.

The development of an integrated system of multi-purpose projects was the natural outcome of the interrelation and interdependence among the various uses of the waters which have been described. Only through such a comprehensive development can the optimum use of water, of sites, and of capital be attained. ${ }^{101}$

99. Ibid.; Clemens, The Reservoir as a Flood Control Structure (1935) 100 TransACtIONS OF AM. Soc. OF Civ. ENGINEERS 879, 905-909.

I00. Id. at 889 .

IOI. The National Resources Board characterizes the problem of water conservation and control as one of "multiple adjustments", a concept which is thus elaborated by the Board: "Interrelations of physical factors, interests and responsibilities make the development of the use and control of water factors a problem of coordination from several points of view. It is this multiplicity of coordinations that makes the problem a real challenge to intelligence and to capacity to plan. . . . Many projects have been reviewed . . . which, although inspired by a single purpose, offer excellent opportunities for combinations which would multiply benefits and reduce the cost of any one benefit below what it would be if sought by itself. Thus a project may at first appear to involve only the element of levee or reservoir control of 
Failure to appreciate the interrelation in the various uses of a single project, failure to appreciate the interrelation between projects, was in part responsible for haphazard private development. The nation became alarmed by the extent to which unrelated projects, designed for single purposes, threatened the future of our rivers. Numerous power dams had been constructed under federal and state authority, but in helter-skelter fashion. ${ }^{\mathbf{1 0 2}}$ The dams were frequently located at points which were disadvantageous from the point of view of navigation and which would not fit into comprehensive plans for navigation improvement. The dams failed to utilize the navigation or flood-control possibilities of the sites, and there was not even assurance of full utilization of power possibilities. Instead of blending into a sound pattern of development, often they were worse than nothing in that they occupied the site and precluded later development according to an intelligent plan.

From the point of view of the private interests responsible for those developments, they had done a good job. They had taken the best power sites and developed them sufficiently to serve contemporary demands; but they were inherently incapable of accomplishing the rounded and integrated development required in the best interests of the whole public. They were, after all, not interested in two of the major purposes of river improvementnavigation and flood control-and they were interested in power only to the extent of immediate demands.

In the planning and development of public projects, power is only one of the many phases of water control which enter into the complete picture. However, it bears a special relation to the others: it is the paying partner. It must be remembered that the other purposes do not pay their own way. There is no feasible way of assessing the benefits of a widespread plan of navigation and flood control; and even reclamation presents difficulties. ${ }^{103}$ Power rights, being valuable, have been coveted by private interests, and their utilization by the Government has been bitterly attacked. Often the Government has been attacked for the expense of the project by the same

floods, but careful consideration may disclose that reservoir control may carry with it opportunities for power generation, water supply for adjacent communities, and recreational facilities. In exceptional instances the same dam and reservoir may be made to serve flood control, irrigation, power, and recreational purposes. A dam conceived at first solely for navigation control may offer also power generation. No matter what the originating purpose, every other reasonable purpose should be considered in defining and planning a water project." NationaL RESOURCES BOARD REPORT (I934) 263-264.

102. For details of hydroelectric power development prior to I920, see Memorandum from Acting Chief of Engineers of the War Departinent Relative to Acts of Congress Concerning Power Privileges at Government Dams, SEN. Doc. No. 57,62d Cong., Ist Sess. (I9II) ; Electric Pozver Development in the United States, SEN. Doc. No. 3I6, 64th Cong., Ist Sess. (I9I5) pt. 2, table 55; REPORT ON WATER POWER DevelopMent IN THE UNITED States (Comm'r of Corps. I9I2) pt. 2; First Annual Report of Federal Power Conrairssion (Ig2I) ; Power Capacity and Production In the United States (Water Supply Paper 579, U. S. Geol. Survey, U. S. Dep't of Int. I928) II3 et seq.

I03. Preliminary Report of President's Commission on Development of the Rivers of the Uitited States, supra note 47, at 54; see National Resources BOARD Report (I934) 275. 
interests that sought to deny it the right of reimbursement by the sale of power.

President Theodore Roosevelt believed that the Government should develop the water power as a part of its navigation improvement, and that no private license should be granted except on the payment to the public for the use of any water-power rights conferred. He drew the essential facts to public attention more than a third of a century ago in a message to Congress vetoing a bill to renew a franchise of the Muscle Shoals Power Company to construct a canal and power station, on the ground that it did not contain any provision for such payment:

"The recent development of the application of water power to the production of electricity available for use at considerable distances has revealed an element of substantial value in streams which the Government is or is liable to be called upon to improve for purposes of navigation, and this value, in my judgment, should be properly utilized to defray the cost of the improvement." 104

The views of President Roosevelt on this subject were stated in more detail in veto messages accompanying the Rainy River and James River bills. ${ }^{105}$ Substantially the same reasons were given by his successor, President Taft, in his veto of a bill for the private construction of a dam on the Coosa River in Alabama. ${ }^{106}$

The wisdom and the right of the Government to pursue this course was endorsed by other leading public men of the day. Elihu Root, in a Senate debate, urged that we should "avail ourselves of this new discovery by which a stream can be made to improve itself, by which a stream can be made to pay the expense of fitting itself for navigation, . . . ." 107 And a subcommittee of the Senate Judiciary Committee, in a report prepared by Senators Root, Nelson, and Chilton, pointed out that

"If, for the purpose of improving the navigability of a stream carrying interstate commerce, the Federal Government constructs and maintains a dam, with locks and gates, the Government has the undoubted right to establish and maintain, in connection with such dam, an electricpower plant for the purpose of furnishing motive power to operate such locks and gates. And the Federal Government has the right to sell, lease, or rent, for compensation, any surplus power that may arise from and be an incident to such an improvement of navigation." 108

I04. 36 CoNG. REC. 307 I (1903).

ro5. 42 id. at 4698 (I908); 43 id. at $978-980$ (1909).

I06. See Sen. Doc. No. 949, 62d Cong., $2 d$ Sess. (I9I2).

I07. 49 CoNG. REC. 3057 (I9I3).

I08. 48 id. at II,568, II,57I (I912). The report was subsequently published as a Senate document; see Pozerer of the Federal Government over Development and Use of Water Power, SEn. Doc. No. 246, 64th Cong., ist Sess. (I916) 17. 
These views represented the logical application of principles enunciated in earlier opinions ${ }^{109}$ of the Supreme Court. In the perspective of the long line of decisions since Gibbons v. Ogden ${ }^{110}$ the right of the Federal Government to use and dispose of the power created at Government projects was an inevitable attribute of its plenary navigation power. When the question came to the Supreme Court in the second Green Bay case, ${ }^{111}$ the Court felt no need to concern itself with complex refinements. It denied the claim of a riparian owner seeking an apportionment of the flow of the Fox River, on which there were federal navigation improvements, and expressly recognized the physical and functional relationships which necessitated a unified control over the river. In upholding the disposition of the water power by the Government, it further pointed out that the Government might thus reimburse itself for the expense of the improvement. The decision seemed simple and natural. It has several times been reaffirmed. ${ }^{112}$

Moreover, the Court has refused to recognize the existence of vested rights which would make the expense of Government improvements prohibitive. In the Chandler-Dunbar case, ${ }^{113}$ it established principles to prevent such a barrier to public development. That case involved condemnation proceedings by the United States in which a power company claimed damages for the taking of water-power rights in excess of navigation needs. The Court vigorously rejected the contention that there could be any private ownership of the water or the power in a navigable stream as against the Federal Government.

But the conservation movement went far beyond the limited issue of Government utilization of power. Power, though then, as today, a center of controversy, was only one interest of the conservationists. Thirty years ago they recognized the need for comprehensive developments preserving all the values inherent in our rivers. ${ }^{114}$ Their policy was to prevent the waste or monopoly of the resources of the country-all of them, minerals, forests, oil, coal, agricultural land, as well as water resources. The aim was to develop the greatest utility in the public interest. As in the case of other natural resources, the conservationists appraised the experience of the past and the potentialities of the future in the field of water resources. They took account of reckless wastes and of natural limitations. They observed that the prior

rog. See Kaukauna Water Co. v. Green Bay \& Miss. Canal Co., I42 U. S. 254, 273 et seq.; Green Bay \& Miss. Canal Co. v. Patten Paper Co., I72 U. S. 58, 8I (I898), rehearing denied, I73 U. S. 179 (1899).

IIo. 9 Wheat. I (U. S. I824).

III. Green Bay \& Miss. Canal Co. v. Patten Paper Co., I72 U. S. 58 (I898), rehearing denied, I73 U. S. I79 (I899).

II2. United States v. Chandler-Dunbar Co., 229 U. S. 53 (Igr3) ; Arizona v. California, 283 U. S. 423 (I93I); Ashwander v. Tennessee Valley Auth., 297 U. S. 288 (I936).

II3. United States v. Chandler-Dunbar Co., 229 U. S. 53 (I9I3).

II4. See Preliminary Report of Inland Waterways Comnnission, snpra note 39; I Report of National Conservation Commission, loc. cit. supra note 39; Final Report of National Waterways Commission, SEN. Doc. No. 469, 62d Cong., $2 \mathrm{~d}$ Sess. (I9r2). 
attempts at regulation had been ineffective. And, considering all these things, they formulated the principles which form the basis of present policy. ${ }^{115}$

A generation ago, President Roosevelt's Conservation Commission recommended comprehensive and unified development of our rivers :

"Broad plans should be adopted providing for a system of waterway improvement extending to all uses of the waters and benefits to be derived from their control, including the clarification of the water and abatement of floods for the benefit of navigation; the extension of irrigation; the development and application of power; the prevention of soil wash; the purification of streams for water supply; and the drainage and utilization of the waters of swamp and overflow lands." 116

This was in I909. As early as I9I2, the National Waterways Commission, created by an Act of Congress ${ }^{117}$ in the Roosevelt administration, submitted its report, which forecast that the Federal Government must inevitably undertake the unified development of river systems by means of multi-purpose projects :

"With the increasing unity of our national life and the growing necessity of securing for human needs the maximum beneficial use of the waters of every stream it will become increasingly necessary to treat every stream with all its tributaries as a unit. In the nature of the case so comprehensive a policy could be successfully administered only by the Federal Government, and consequently, the eventual desirability of Federal control is easy to predict." ${ }^{118}$

By I9I6 these recommendations had found expression in legislative proposals which were debated on the floor of the Congress. Thus, in connection with the Shields bill in I9I6, Senator Newlands offered a comprehensive amendment ${ }^{119}$ in twenty sections providing for an appropriation of sixty million dollars a year for ten years for the development of water highways, the storage of water for irrigation, and the construction of huge reservoirs to stabilize water flow. Under this proposal the country was to be divided into regions corresponding to watershed areas. Provision was made for scientific investigation of each drainage basin and for formulating plans for coordinated comprehensive development. The proposal failed at the time, ${ }^{120}$ but the policies which were implicit have been incorporated in whole or in part in all the important legislation subsequently enacted on the subject of water utilization.

II5. See I Report of National Conservation Commission, supra note 39, at I3-26.

II6. Id. at 24 .

II7. 35 STAT. 8I8 (Ig09).

I18. Final Report of National Waterways Commission, supra note II4, at 52.

I19. 53 CoNG. REC. $3733-3736$ (rgI6).

I20. See KerWIn, Federal WATER-PoWer Legislatton (I926) 205-216. 
On the side of regulation, the Federal Water Power Act of $1920^{121}$ represents the application of these policies. ${ }^{122}$ By that Act plans for private development were subjected to Commission control in order to assure more complete utilization of water resources for navigation, hydroelectric power, or other beneficial uses. ${ }^{123}$ But the nature of the problem is such that regulatory legislation, however well administered, cannot fully promote the coordinated development and the integrated operation of projects. In part, the Federal Water Power Act also provided for investigation of and planning for direct undertakings by the Government. ${ }^{124}$ Other legislation, such as that which led to the " 308 " reports, ${ }^{125}$ likewise took account of this approach to the problem. And in recent years the Government has itself undertaken large-scale multi-purpose projects embodying in high degree the conservationists' principles. The Government's projects, such as the Boulder Canyon project and those in the Columbia River basin and the Tennessee Valley, are multi-purpose undertakings, which, through unified planning and operation, reconcile the inherent conflicts in the control and utilization of water and attain the maximum benefits. ${ }^{126}$

Apparently conservation principles run in blood rather than political lines. For it remained to President Franklin D. Roosevelt to give the fullest expression to the principles of the conservationists. The best articulation and the first practical conception of their application on a nation-wide basis is found in the pending measure endorsed by the President providing for the creation of seven conservation authorities. ${ }^{127}$ Although the House and Senate versions of the measure, on which hearings were held in the last

I2I. 4I StAT. I063 (I920), I6 U. S. C. A. \$ 792 (I927).

I22. For the background of this legislation, see First ANnuat Report of Federal Power Commission (I921) 44-50; Conover, The Federal Power Commission (Ig23) c. I; KERWIN, op. cit. supra note I20, at c. 5; McNinch, The Evolution of Federal Control of Electric Power (1936) I2 J. OF LAND \& PUB. UTIL. ECON. III, II4-II5.

123. The constitutionality of the Act was upheld in Alabama Power Co. v. Gulf Power Co., 283 Fed. 606 (M. D. Ala. I922). In New Jersey v. Sargent, 269 U. S. 328 (1926), the Supreme Court refused to entertain a bill by a state for an injunction against the members of the Federal Power Commission on the ground that the bill did not show that any right of the state which in itself was an appropriate subject of judicial cognizance was being affected prejudicially by the enforcement of the Act. In Appalachian Power Co. v. Smith, 4 F. Supp. 6 (W. D. Va. 1933) the constitutionality of the Act was again upheld, but on appeal the decree was reversed and the case remanded with directions that the suit be dismissed for lack of jurisdiction, 67 F. (2d) 45 I (C. C. A. 4th, I933), cert. denied, 29 I U. S. 674 (I934). See also United States v. West Virginia, 295 U. S. 463 (1935). For detailed discussions of the constitutional aspects of the Act, see Elder, Use of Water Pozerer in the Generation of Electricity (I93I) 25 ILL. L. REv. 759 ; Shields, The Federal Pozver Act (I925) 73 U. of PA. I. Rev. I42; (I933) 22 GE0. L. J. IO3, 32 MICH. L. REv. ror.

124. 4I Stat. I067-I068 (I920), I6 U. S. C. A. §800 (I927).

I25. 43 STAT. IIgO (1925).

I26. 45 Stat. I057 (1928), 43 U. S. C. A. \$6I7 (Supp. I936); 48 STAT. 58 (I933), as amended by 49 STAT. 1075 (I935), I6 U. S. C. A. § 83 I (Supp. 1936); 49 STAT. I039 (I935).

127. S. 2555, 75th Cong., Ist Sess. (1937) ; H. R. 7365, 75th Cong., Ist Sess. (1937); H. R. 7863, 75th Cong., Ist Sess. (I937). For text of the President's message, see N. Y. Times, June 4, I937, p. I2, col. 3. 
session of Congress, ${ }^{128}$ differ in some important details, they are essentially the same in providing for the development of plans for integrated watercontrol projects by the several authorities charged with jurisdiction for the respective regions defined in the bills. The legislation likewise sets up the machinery for the development and unified operation of the projects themselves, as they may be authorized by Congress.

\section{Conclusion}

Today the general course of the development of water conservation is thrown out of perspective by the controversy centered upon one isolated issue-hydroelectric power. There is always the danger that, becoming absorbed in the spectacle of passing conflict, we shall fail to observe the orderly processes of evolution which are at work. From the outset, the relation of the National Government to the use and control of the waterways has been a critical issue fought out on many fronts. From the time of the Revolution the general problem, in the broad setting which it occupied, has been confused by the attacks of particular interests upon some single phase affecting them and by the political form which those attacks assumed.

Sometimes, in an effort to compose these conflicts, the Government adopted a local approach to national undertakings. However, history has demonstrated that a local or private approach to these essentially national problems must in the end fall short. The conflicts must be recognized as incidents in the historical process. From the compromise of the conflicts and the clashes of interests in the past, and their adjustment to national needs, there emerged the concept which prevails today: integrated multiple-purpose projects which develop for the social good the full potentialities of a river system. And, as the social, the economic, the engineering forces have thrust upon the Federal Government the responsibilities which it now holds, they have been woven into the fabric of the law.

128. Hearings Before Sub-Committee of the Connmittee on Agriculture and Forestry on S. 2555, 75th Cong., Ist Sess. (I937) ; Hearings Before Committee on Rivers and Harbors on H. R. 7365 and H. R. 7863,75 th Cong., Ist Sess. (I937). 